\title{
Laser Nephelometric Measurement of Seven Serum Proteins Compared with Radial Immunodiffusion
}

\author{
By M. Guiguet, P. Padieu, G. Mack
}

Laboratoire d'Exploration Fonctionnelle en Chimie Biologique, Hôpital du Bocage, Centre Hospitalier Universitaire, Dijon, France and

\section{Dalebroux}

Station d'Amélioration des Plantes, Institut National de la Recherche Agronomique, Dijon, France

(Received June 2/August 31, 1982)

Summary: Quantification of immunoglobulins IgG, IgA, IgM, $C_{3}$ complement, siderophilin, $\alpha_{2}$-macroglobulin and haptoglobin in serum by a Behring laser nephelometer coupled with a data processing apparatus was compared with values obtained by the radial immunodiffusion method of Mancini. The precision was not improved by the use of the laser nephelometer as compared to Mancini radial immunodiffusion, but within run precision was better than that among runs for both methods. The analytical recovery studies for laser nephelometry showed a close concordance between the theoretical and measured values for all proteins. The two techniques were also compared by means of correlation studies.

\section{Lasernephelometrische Bestimmung von sieben Serumproteinen im Vergleich zur radialen Immunodiffusion}

Zusammenfassung: Die Konzentrationen der Immunoglobuline IgG, IgA und IgM, der $\mathrm{C}_{3}$ KomplementKomponente, von Siderophilin, $\alpha_{2}$-Makroglobulin und Haptoglobulin wurden mit Hilfe eines an einen Computer angeschlossenen Behring-Lasernephelometers bestimmt und mit den Ergebnissen der radialen Immundiffusion nach Mancini verglichen. Die lasernephelometrische Messung verbessert die Präzision nicht. In beiden Verfahren ist jedoch die Präzision in der Serie besser als die zwischen den Serien. Die Wiederfindungsteste beweisen, daß für alle lasernephelometrischen Bestimmungen eine sehr gute Übereinstimmung zwischen den erwarteten und den gemessenen Werten besteht. Die beiden Verfahren wurden auch durch Korrelationsteste geprüfț.

\section{Introduction}

In quantifying serum proteins, laser nephelometry is becoming more and more routinely used instead of radial immunodiffusion. This is due to the fact that the latter is slow and laborious, and cannot be performed automatically, whereas laser nephelometry allows easy automatic handling of sera, so that large numbers of specimens can be analysed at relatively low cost with satisfactory statistical precision. From this standpoint, Alexander (1), in a quite recent paper, compares the two methods for quantifying IgG, $\operatorname{IgA}, \operatorname{IgM}, \mathrm{C}_{3}$ and $\mathrm{C}_{4}$, and provides a list of references on the subject.
The present study compares the laser nephelometry quantification of the serum proteins $\operatorname{IgG}, \operatorname{IgA}, \operatorname{IgM}$, $\mathrm{C}_{3}$ complement, siderophilin, $\alpha_{2}$-macroglobulin and haptoglobin with values obtained by the radial immunodiffusion method of Mancini (2).

\section{Materials and Methods}

Instrumentation

Laser nephelometrie analyses were made with a Bchring Laser Nephelometer. The data processing apparatus was a $9815 \mathrm{~A}$ Hewlett-Packard, and the dilutor was a Hamilton digital dilutor. 
All three instruments were supplied by Hoechst-Behring (F75008 Paris).

\section{Reugents}

Hocchst-Behring supplied Tri-partigen plates for IgG, IgA and IgM, and $M$-partigen plates for $C_{3}$, siderophilin, $\alpha_{2}$-macroglobulin and haptoglobin. Hoechst-Behring radial immunodiffusion standards were also used, except for the $\mathrm{C}_{3}$ standard, which was bought from Hyland (Laboratoires Travenol, Plaisir, France). Laser nephelometric analyses were performed with laser standard serum as a compound reference, and nephelometric laser-grade antisera from Behring. However, the laser standard serum was retitrated by radial immunodiffusion on $\mathrm{C}_{3} \mathrm{M}$-partigen plates. and compared with the Hyland complement $C_{3}$ reference serum. Consequently, it was possible to compare, on the basis of a common reference. $C_{3}$ values obtained by the two methods.

\section{Procedures}

Radial immunodiffusion was carricd out according to the method of Mancini. The measurements of the diameters of the precipitin rings were made by means of a Desaga Measuring Projector Multiskop (C. Desage GmbH, D-6900 Heidelberg 1).

Laser nephelometry was performed according to the Behring method, strictly following the manufacturer's recommendations listed in the table of instructions for the use of the Behring Nephelometer. For IgG, it should be pointed out that the $10 \mu \mathrm{l}$ serum sample was used, so that the final dilution was $1: 101$. The incubation time for IgM was $45 \mathrm{~min}$, whereas that for all the other proteins tested was $30 \mathrm{~min}$. The reading time chosen was $15 \mathrm{~s}$.

\section{Specimens}

The blood samples were collected from patients (Hôpital du Bocage, Dijon). However, turbid and grossly lipaemic sera were discarded; in addition. sera containing monoclonal immunoglobulin detected by immunoelectrophoresis were eliminated. Since the study was carried out over a 3-week period, all serum samples were preserved with $1 \mathrm{~g} / \mathrm{l}$ sodium azide and kept at $4{ }^{\circ} \mathrm{C}$.

\section{Statistical methods}

The study of precision was made through "within run" and "between runs" sample analyses. For both methods, low-content and high-content samples were examined and the precision expressed in terms of the coefficient of variation (CV \%). The sample sizes for the "within run" and "between runs" studies were 10 and 20 , respectively, but the pooled serum for radial immunodiffusion was in most cases different from that used for laser nephelometry. This could explain differences observed for some proteins between the two methods.

Laser nephelometric recovery studies were performed as follows. For each protein, a low-content pooled sample as well as a highcontent pooled sample were prepared. Each of these was analysed seven to ten times by laser nephelometry. The two means were taken as reference points from which a scale of four intermediate theoretical equally spaced values was constructed by mixing the low and high sera in $4: 1,3: 2,2: 3$ and $1: 4$ proportions. Each of the four intermediate mixtures was analyzed three times by laser nephelometry. This procedure, already utilized by Adlercreutz et al. (3), was chosen for the determination of recovery, because the pure proteins are not commercially available. Two linear regression analyses were carried out on each of the seven sets of data : one according to the general linear regression model, and one on the model through the origin. The null hypothesis $\mathrm{H}_{0}$ : intercept $a=0$ versus the alternative hypothesis $H_{1}:$ intercept $\alpha \neq 0$ was tested by F. Also, the coefficient of determination, $r^{2}$ (4), was given on the basis of the ANOVA performed on the chosen model. The final linear regression equation was chosen by testing whether the true slope $\beta$ was equal to, or different from, 1 .
The two quantifying methods werc compared by linear regression analyses of laser nephelometry (y) on radial immunodiffusion ( $x$ ), the latter being considered as the reference standard, and the significance of the intercept was tested. In each ANOVA, the number of ordered pairs was 120 , except for the comparison of siderophilin quantification, when only 100 samples were used. The data were collected from routinely tested patients. Contrary to the recovery tests, both variables were randopm, so that the correlation coefficient could be rightfully used as a measure of the closeness of association of the two variates. Furthermore, a $95 \%$ confidence interval for each true correlation coefficient, $\varrho$, was calculated. Also, prediction cquations are given for laser nephelometry on radial immunodiffusion. Finally, the equation of the orthogonal regression line is provided for each protein (5).

\section{Results}

Table 1 presents the precision studies. Analytical recovery studies for laser nephelometry and the com= parison between the two quantifying methods are shown in tables 2 and 3, respectively.

\section{Precision}

Coefficients of variation are meaningful in comparing samples on the bases of their respective variabilities, only when both mean and variance are known in each sample. The comparison between two samples . on the basis of their CV \% is especially easy when the means are approximately equal. In such a case, a difference in $\mathrm{CV} \%$ can be fully attributed to a difference in standard deviation, and therefore in vāriability. This is why it is important that "within run" and "between runs" trials for a given protein be performed on the same serum pool. However, since laser nephelometry and radial immunodiffusion quantifications for a given protein were not always made on the same pool of sera, horizontal comparisons in table 1 are somewhat more hazardous than those made vertically.

\section{Analytical Recovery}

Analytical recovery studies for laser nephelometry are summarized in table 2 following the outline presented in the section on Statistical Methods:

\section{Comparison between methods}

For each protein, table 3 presents the results gathered in accordance with the design proposed in the section on Statistical Methods. 
Tab. 1. Precision study of the trials

\begin{tabular}{|c|c|c|c|c|c|c|c|c|}
\hline & \multicolumn{4}{|c|}{ Radial immunodiffusion } & \multicolumn{4}{|c|}{ Laser nephelometry } \\
\hline & \multicolumn{2}{|c|}{ Low-content } & \multicolumn{2}{|c|}{ High-content } & \multicolumn{2}{|c|}{ Low-content } & \multicolumn{2}{|c|}{ High-content } \\
\hline & $\begin{array}{l}\text { Mcan } \\
(g / l)\end{array}$ & $\begin{array}{l}\text { CV } \\
(\%)\end{array}$ & $\begin{array}{l}\text { Mean } \\
(\mathrm{g} / \mathrm{l})\end{array}$ & $\begin{array}{l}\text { CV } \\
(\%)\end{array}$ & $\begin{array}{l}\text { Mean } \\
(\mathrm{g} / \mathrm{l})\end{array}$ & $\begin{array}{l}\text { CV } \\
(\%)\end{array}$ & $\begin{array}{l}\text { Mean } \\
(\mathrm{g} / \mathrm{l})\end{array}$ & $\begin{array}{l}\text { CV } \\
(\%)\end{array}$ \\
\hline \multicolumn{9}{|l|}{ Within run $(n=10)$} \\
\hline $\operatorname{lgG}$ & 7.50 & 5.5 & 16.67 & 3.0 & 8.95 & 3.3 & 18.60 & 4.5 \\
\hline $\lg A$ & 0.84 & 5.9 & 3.13 & 4.4 & 0.87 & 4.5 & 3.53 & 2.3 \\
\hline $\lg M$ & 0.81 & 2.6 & 2.35 & 1.8 & 0.51 & 21.6 & 2.43 & 5.9 \\
\hline$C_{3}$ & 1.55 & 5.7 & 1.85 & 5.9 & 1.57 & 7.1 & 2.34 & 7.6 \\
\hline Sidcrophilin & 2.12 & 3.3 & 4.02 & 2.5 & 1.56 & 2.9 & 3.44 & 4.0 \\
\hline$a_{2}-$ Macroglobulin & 2.89 & 10.1 & 3.63 & 2.4 & 2.56 & 5.2 & 2.88 & 3.6 \\
\hline Haptaglobin & 1.88 & 2.8 & 4.30 & 4.9 & 1.16 & 2.6 & 3.04 & 3.7 \\
\hline \multicolumn{9}{|l|}{ Between runs $(n=20)$} \\
\hline $\lg G$ & 8.35 & 6.7 & 16.47 & 4.2 & 9.02 & 8.9 & 17.49 & 10.3 \\
\hline $\lg A$ & 0.80 & 7.6 & 3.07 & 7.3 & 0.86 & 6.4 & 3.61 & 8.8 \\
\hline $\lg M$ & 0.80 & 11.3 & 2.42 & 6.8 & 0.72 & $29: 0$ & 2.54 & 14.5 \\
\hline $\mathrm{C}_{3}$ & 1.46 & 7.0 & 1.75 & 6.9 & 1.57 & 9.4 & 2.41 & 9.2 \\
\hline Siderophilin & 1.85 & 9.6 & 3.85 & 9.3 & 1.68 & 15.3 & 3.53 & 14.4 \\
\hline (12-Macroglobulin & 2.73 & 11.9 & 3.74 & 6.2 & 2.57 & 12.5 & 3.21 & 14.2 \\
\hline Haptoglobin & 1.86 & 5.9 & 4.14 & 15.9 & 1.16 & 2.5 & 3.04 & 6.0 \\
\hline
\end{tabular}

Tab. 2. Analytical recovery studies for Laser Nephelometry

\begin{tabular}{|c|c|c|c|c|c|c|}
\hline Proteins & $\begin{array}{l}\text { Range } \\
\text { investigated } \\
(\mathrm{g} / \mathrm{l})\end{array}$ & $\begin{array}{l}\text { Significance } F \\
\text { test for } \\
\mathrm{H}_{0}: \alpha=0 \text { vs } \\
\mathrm{H}_{1}: \alpha \neq 0\end{array}$ & $\begin{array}{l}\text { Chosen linear } \\
\text { equation }\end{array}$ & $\begin{array}{l}\text { Coefficient of } \\
\text { determination } \\
r^{2}\end{array}$ & $\begin{array}{l}\text { Significance } t \\
\text { test for } \\
H_{10}: \beta=1 \text { vs } \\
H_{1}: \beta \neq 1\end{array}$ & $\begin{array}{l}\text { Final linear } \\
\text { regression } \\
\text { equation }\end{array}$ \\
\hline IgG & $8.95-18.60$ & $0.04 \mathrm{~ns}$ & $\hat{y}_{i}=1.0026 x_{i}$ & 0.9970 & $0.26 \mathrm{~ns}$ & $\hat{y}_{i}=x_{i}$ \\
\hline IgA & $0.87-3.54$ & $1.26 \mathrm{~ns}$ & $\hat{y}_{i}=0.9841 x_{i}$ & 0.9989 & 2.69 & $\hat{y}_{i}=0.9841 x_{i}$ \\
\hline $\operatorname{lgM}$ & $0.51-2.43$ & $0.04 \mathrm{~ns}$ & $\hat{y}_{i}=0.9900 x_{i}$ & 0.9957 & $0.85 \mathrm{~ns}$ & $\hat{y}_{i}=x_{i}$ \\
\hline $\mathrm{C}_{3}$ & $1.18-2.94$ & $0.07 \mathrm{~ns}$ & $\hat{y}_{i}=0.9916 x_{i}$ & 0.9986 & $1.20 \mathrm{~ns}$ & $\hat{y}_{i}=x_{i}$ \\
\hline Siderophilin & $1.31-2.47$ & $0.99 \mathrm{~ns}$ & $\hat{y}=0.9882 x_{i}$ & 0.9982 & $1.49 \mathrm{~ns}$ & $\hat{\mathrm{y}}_{\mathrm{i}}=\mathrm{x}_{\mathrm{i}}$ \\
\hline$\alpha_{2}$-Macroglobulin & $2.32-3.48$ & $0.08 \mathrm{~ns}$ & $\hat{y}=0.9803 x_{i}$ & 0.9980 & 2.41 & $\hat{y}_{i}=0.9803 x_{i}$ \\
\hline Haptoglobin & $1.30-3.46$ & $0.10 \mathrm{~ns}$ & $\hat{y}_{i}=1.0200 x_{i}$ & 0.9981 & 2.32 & $\hat{\mathrm{y}}_{\mathrm{i}}=1.0200 \mathrm{x}_{\mathrm{i}}$ \\
\hline
\end{tabular}

$y_{i}=$ Value of the protein measured by laser nephelometry

$\mathbf{x}_{\mathrm{i}}=$ Protein content theoretical value

ns: Not significant; unmarked $t$ values are significant at $P$ (type $I$ error) $<0.05$

Tab. 3. Comparison of radial immunodiffusion (RID) and laser nephelometry (LN) by regression and correlation studies

\begin{tabular}{|c|c|c|c|c|c|c|}
\hline \multirow[t]{2}{*}{ Proteins } & \multicolumn{2}{|c|}{ Range investigated $(\mathrm{g} / \mathrm{l})$} & \multirow[t]{2}{*}{ Linear regression of $y$ on $x$} & \multirow[t]{2}{*}{$\mathbf{r}$} & \multirow[t]{2}{*}{$I_{0.95}$ for $Q$} & \multirow[t]{2}{*}{ Orthogonal regression line } \\
\hline & $y(L N)$ & $x(R I D)$ & & & & \\
\hline $\lg G$ & $3.20-26.84$ & $3.20-23.20$ & $\hat{y}_{i}=1.1616 x_{i}$ & 0.9568 & $0.9385-0.9697$ & $\hat{y}_{i}=-0.4537+1.2060 x_{i}$ \\
\hline IgA & $0.54-6.56$ & $0.80-5.12$ & $\hat{y}_{i}=-0.3516+1.2957 x_{i}$ & 0.9736 & $0.9623-0.9816$ & $\hat{y}_{i}=-0.4582+1.3409 x_{i}$ \\
\hline IgM & $0.32=2.72$ & $0.26-2.38$ & $\hat{y}=1.0853 x_{i}$ & 0.9770 & $0.9671-0.9839$ & $\hat{y}_{i}=-0.0276+1.1093 x_{i}$ \\
\hline$\epsilon_{3}$ & $0.71-2.62$ & $0.78-2.48$ & $\hat{y}_{i}=1.0763 \mathrm{x}_{i}$ & 0.9614 & 0.945()$-0.9730$ & $\hat{y}_{i}=-0.0682+1.1242 x_{i}$ \\
\hline Siderophilin & $0.54-2.80$ & $0.60-2.70$ & $\hat{y}_{i}=0.9954 x_{i}$ & 0.9911 & $0.9868-0.9940$ & $\hat{y}_{i}=-0.0321+1.0117 x_{i}$ \\
\hline$a_{2}$-Macroglobulin & $0.40-3.48$ & $0.96-3.40$ & $\hat{y}_{i}=-0.6112+1.0660 x_{i}$ & 0.9650 & $0.9501-0.9755$ & $\hat{y}_{i}=-0.6953+1.1085 x_{i}$ \\
\hline Haptoglobin & $0.53-5.72$ & $0.60-5.64$ & $\hat{y}_{i}=0.9192 x_{i}$ & 0.9472 & $0.9250-0.9630$ & $\hat{y}_{i}=-0.0933+0.9589 x_{i}$ \\
\hline
\end{tabular}

\section{Dișcusssion}

From the CV \% (tab. 1), it can be said that for both laser nephelometry and radial immunodiffusion, the within run precision is somewhat better than that among runs. Except for a few values, our CV \% data seem to be in fairly good agreement with Alexander's results (1). It should be kept in mind, however, that we present quantifications made over a wide range 
of values for both methods, whereas Alexander made analyses on normal sera. Deaton at al. (6) quantified $\operatorname{IgG}, \operatorname{Ig} A, \lg M$ and $C_{3}$, with a Hyland Laser Nephelometer, for sera ranging from low up to high pathological values. Their CV \% values are somewhat better than ours, but the sample sizes used by these authors were 20 and 55 for "within run" and "between runs", respectively. This may explain part of the discrepancies. It should be pointed out that our lowcontent laser nephelometric values for IgM yield abnormally high CV \% for both "within run" and "between runs" assays (21.6 and 29.0).

Buffone \& Lewis (7) studied a pediatric population for $\mathrm{C}_{3}$ in order to establish immunochemical reference limits. Their "within run" $(n=20)$ and "between runs" $(n=26) \mathrm{CV} \%$ were 3.9 and 4.5 , respectively (Hyland Laser Nephelometer). These values are about half as high as those we obtained with the Behring apparatus; however, our "within run" sample size was only 10 . Buffone's radial immunodiffusion "between runs" CV \% was equal to 4.9 while ours is about 7.0 for both low and high content sera. Walsh et al. (8) carried out a comparative study of "PDQ"-Hyland laser nephelometer, Behring laser nephelometer and radial immunodiffusion in measuring IgG. For a sample size equal to 10 on a pool of normal sera, the "within run" means (and CV \%) were 8.19 (2.07), 11.25 (3.78) and 12.55 (2.23) for Hyland, Behring and radial immunodiffusion, respectively, and comparable to our values (Behring and radial immunodiffusion). This also roughly holds for the "between runs" values obtained on 20 days. As for the additional three proteins, i. e., siderophilin, $\alpha_{2}$-macroglobulin and haptoglobin, the "within run" CV \% appear to be fairly satisfactory, whereas the "between runs" CV \% are rather high for both Behring laser nephelometry and radial immunodiffusion.

To summarize the discussion on precision, table 1 shows that the use of a Behring Laser Nephelometer does not seem to improve the precision of the results as compared to Mancini's method. However, as pointed out in the Introduction, laser nephelometry offers the possibility of an automated analytical method which can be operated under satisfactory conditions.

According to our study, the proportion of recovery (tab. 2) is practically equal to 1.00 for all seven proteins. This proportion is equal to the slope of the regression line in column 4 , obtained after analysis of variance, or to that in column 7 , chosen on the basis of an additional $t$ test for $\mathrm{H}_{0}: \beta=1$. The practically admissible figures are 1.00 for $\operatorname{IgG}, \operatorname{IgM}, C_{3}$ and siderophilin, 0.98 for IgA and $\alpha_{2}$-macroglobulin, and 1.02 (slight "over-recovery") for haptoglobin. Since, in addition, the $r^{2}$ values are all very close to 1 , it can be concluded that there is a close agreement between the theoretical and laser nephelometric measured quantities.

The seven regression equations for the comparison of both methods are presented in table 3; except for siderophilin, all the slopes are statistically different from 1 . Considering the regression of laser nephelometry on the radial immunodiffusion standard, all the slopes that are different from 1 are larger than 1 , with the exception of haptoglobin for which $\mathrm{b}=0.9192$. Apart from $\operatorname{IgA}$ and $\alpha_{2}$-macroglobulin, all intercepts were found to be statistically equal to zero.

As compared to the results of Alexander (1), who studied Behring laser nephelometry versus radial immunodiffusion - the latter being performed by the technique of Fahey \& McKelvey (9) - for quantifying $\mathrm{IgG}, \operatorname{IgA}, \operatorname{IgM}$ and $\mathrm{C}_{3}$, our regression equations are somewhat better. This is mostly due to the fact that our equations, except that for IgA, do not have intercepts:

- for IgG, our relationship, $y=1.1616 x$, yields laser nephelometric values that are $16 \%$ higher than the corresponding radial immunodiffusion values; Alexander's equation, $\mathrm{y}=1.427+1.054 \mathrm{x}$, provides laser nephelometric values that are about $50 \%, 17 \%$ and $11 \%$ higher than radial immunodiffusion values for very low- $(3.2 \mathrm{~g} / \mathrm{l})$, medium- $(12.0 \mathrm{~g} / \mathrm{l})$ and highcontent $(26.8 \mathrm{~g} / \mathrm{l})$ sera, respectively;

- for IgM, the comparison is as follows: our equation, $y=1.0853 \mathrm{x}$, yields laser nephelometric values that are overestimated by $8.5 \%$ as compared to radial immunodiffusion, whereas Alexander's $\mathrm{y}=0.017+1.114 \mathrm{x}$ provides $17-, 12$ - and $12 \%$ overstimated values for $0.32,1.60$ and $2.70 \mathrm{~g} / \mathrm{l}$ sera, respectively;

- for $C_{3}$, our overestimation, by $y=1.0763 x$, is $7.6 \%$, while those of Alexander, by $\mathrm{y}=0.236+0.866 \mathrm{x}$, are $34 \%, 13 \%$ and $2 \%$ for 0.5 , 0.9 and $1.5 \mathrm{~g} / 1$ sera, respectively;

- for IgA, the situation is different since our equation also has an intercept; on the basis of $y=-0.3516+1.2957 x$, oụr laser nephelometric/ radial immunodiffusion differential percentages are $-35 \%,+14 \%$ and $+24 \%$ as compared to those of Alexander $(\mathrm{y}=0.118+1.153 \mathrm{x}) ;+37 \%,+21 \%$ and $+17 \%$, for $0.54,2.20$ and $6.5 \mathrm{~g} / 1$ sera, respectively. 
It should be noted, however, that Alexander's equations were established on the basis of normal sera, whereas ours were derived from a wide range of values: low, medium and high. This means that in reality, the comparison is fair only for medium values. Even so, our laser nephelometric/radial immunodiffusion relationships are better than those proposed by Alexander. This is most probably due to the fact that the Mancini technique is more accurate than that of Fahey \& McKelvey.

Daigneuault \& Lemieux (10) carried out the Behring laser nephelometry/Mancini radial immundiffusion comparison for IgG, IgA and IgM. Their results are excellent and our data suffer from the comparison, especially for $\lg A$ where our equation is not satisfactory.

Schmitz-Huebner et al. (11), comparing Behring laser nephelometry to Mancini's radial immundiffusion for $\alpha_{2}$-macroglobulin, propose a regression equation that is far better than ours, except for high-content sera. The slope of our equation is better than theirs, as it is closer to 1 , but our total relationship is distorted by a heavy negative intercept.

Given the results obtained by studies on precision, analytical recovery and comparison of methods, it can be stated that on the whole, nephelometric quantification of a wide spectrum of proteins can replace the heavy radial immunodiffusion technique in laboratories involved in the analysis of large numbers of serum specimens.

\section{References}

1. Alexander, R. L. (1980) Clin. Chem. 26, 314-317.

2. Mancini, G., Carbonara, A. C. \& Heremans, J. F. (1965) Immunochemistry 2, 235-254.

3. Adlercreutz, H., Peltonen, V. \& Voipio, T. (1975) Clin. Chem. 21, 676-684.

4. Steel, R. G. D. \& Torrie, J. H. (1980) Principles and procedures of statistics, second edition, McGraw-Hill, New York p 276.

5. Dagnelie, P. (1969) Théorie et méthodes statistiques, Vol. 1, J. Duculot, S. A., Gembloux, Belgium pp 81-86.
Finally, it is fair to mention that other authors have already published similar studies. However, our paper is different for the following reasons:

- the authors mentioned have reported results for only a few proteins, or just a single protein $(7,8)$;

- the proteins analysed by the different authors were not all quantified by means of the same Laser Nephelometer $(1,10,11$ : Behring; 6, 7: Hyland; 8: both Behring and Hyland, but for one protein only);

- radial immunodiffusion was performed by two different techniques (1, 8: Fahey \& McKelvey; 6, 10, 11: Mancini; 7: both techniques, but for one protein only);

- none of the authors cited has reported on a comparative study of haptoglobin quantification by the two methods.

In contrast, we present compared quantifications of seven proteins, all carried out by the same technique of radial immunodiffusion (Mancini) on the one hand, and by the same Laser Nephelometer (Behring) on the other. Furthermore, all our results for each protein involve a wide range of low, medium and high values.

\section{Acknowledgements}

We are grateful to Mesdames D. Sommet, A. Buliard and M. C. Petitjean for their invaluable technical assistance.

6. Deaton, C. D., Maxwell,.K. W., Smith, R. S. \& Creveling, R. L. (1976) Clin. Chem. 22, 1465-1471.

7. Buffone, G. J. \& Lewis, S. A. (1977) Clin. Chem. 23, 994999.

8. Walsh, R. L., Coles, M. E. \& Geary, T. D. (1979) Clin. Chem. 25, 151-156.

9. Fahey, J. L. \& McKelvey, E. (1965) J. Immunol. 94, 84-90.

10. Daigneault R. \& Lemicux, D. Clin. Biochem. 11.28-31.

11. Schmitz-Huebner, U., Nachbar, J. \& Asbeck, F. (1980) J. Clin. Chem. Clin. Biochem. 18, 221-225.

M. Guiguet

Hôpital du Bocage

CHU

F-21034 Dijon 


\section{•}

